\title{
DIGITALIZATION OF LOCAL RASHDUL QIBLA BY QIBLA DIAGRAM
}

Muhammad Thoyfur

Ma'had Takhassus Simbang Kulon Pekalongan

thoyfur.muhammad@gmail.com

\section{Abstract :}

Determination of the direction of qibla develops all the time, starting from the simple way by using the celestial bodies such as the sun with mathematical formulas, using instrumentation such as compasses, rubu'ul mujayyab, mizwala, istiwa'aini, until using the method of combining mathematical formulas and observation tools into digital methods. One method of determining the direction of qibla is Rashdul Qibla method which has two methods, namely Local Rashdul Qibla and Global Rashdul Qibla. This study utilizes the Local Rashdul Qibla method to become instrumentation called Qibla Diagram, this instrumentation is a combination of mathematical calculation in the Microsoft excel program and diagram of Local Rashdul Qibla. This research is a qualitative research based on exploration. Primary and secondary data collection was carried out by experiment and documentation, processed through three stages, namely codification, presentation and conclusions. Then analyze the data using descriptive analysis with the method of inductive thinking. The research resulted in two findings, there are the Microsoft Excel Qibla Diagram calculation program and the Qibla Diagram instrument. The use of the Qibla Diagram is the same as the use of Local Rashdul Qibla, which is local, but the local of the Qibla Diagram has a large enough extent to cover an area of the city and this instrument, digitally, can be used to determine the local Rashdul Qibla throughout the earth's coordinates

Keyword : Direction of Qibla, Rashdul Qibla, Local Rashdul Qibla, Qibla Diagram 


\section{Abstrak :}

Penentuan arah kiblat berkembang sepanjang waktu, mulai dari cara sederahana menggunakan benda langit seperti matahari dengan rumus matematis, menggunakan alat bantuan seperti kompas, rubu'ul mujayyab, mizwala, istiwa'aini, hingga metode penggabungan antara rumus matematis dan observasi alat menjadi metode digital. Salah satu metode penentuan arah kiblat adalah metode Rashdul Kiblat yang terdiri dari Rashdul Kiblat lokal dan Rashdul Kiblat global, Penelitian ini memanfaatkan metode Rashdul Kiblat lokal menjadi sebuah alat yang bernama Qibla Diagram, alat tersebut adalah gabungan dari perhitungan yang dirancang melalui Program Perhitungan matematis microsoft excel dan diagram Rashdul Kiblat lokal. Penelitian ini merupakan penelitian kualitatif berbasis explorasi. Pengumpulan data primer dan sekunder dilakukan dengan eksperimen dan dokumentasi, diolah melalui tiga tahapan, yaitu kodifikasi, penyajian dan penarikan kesimpulan. Kemudian Analisa data menggunakan Analisa deskriprif dengan metode berfikir induktif. Penelitian menghasilkan dua temuan, yaitu program perhitungan microsoft excel Qibla Diagram dan alat Qibla Diagram, Penggunaan Qibla Diagram sama dengan penggunaan Rashdul Kiblat lokal, yaitu bersifat lokal, namun sifat lokal dari Qibla Diagram memiliki batas yang cukup luas hingga mencakup satu wilayah kota dan secara digital alat ini dapat digunakan untuk menentukan Rashdul Kiblat lokal di seluruh koordinat bumi.

Kata Kunci: arah kiblat, Rashdul Kiblat, Rashdul Kiblat lokal, Qibla Diagram

\section{A. Introduction}

One of the conditions for the validity of prayer (something that is determined before the prayer is held, and the obligation before praying) is facing the Qibla, ${ }^{1}$ meaning that we have to know the qibla direction before praying. Therefore, if we fail to know it, our praying is not valid. Qibla is a Ka'bah which located in Mecca. Several verses in the al-Qur'an explain the direction of the Qibla such as the chapter Q.S alBaqarah verse 144:

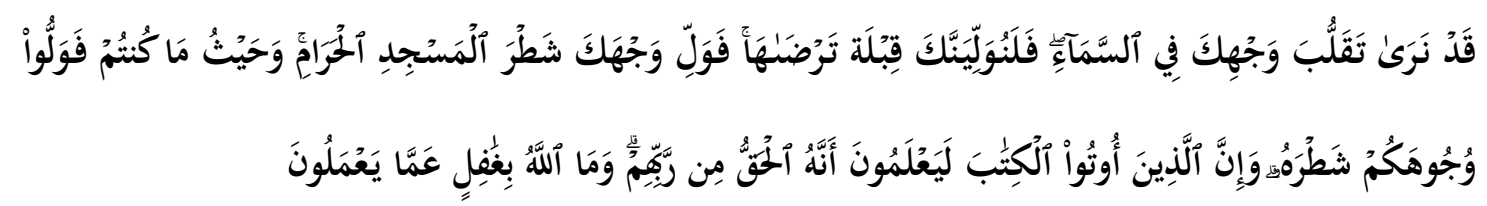

"Indeed, We (often) see your face looking up to the sky, then indeed We will turn you to the Qibla that you like. Turn your face towards the Masjidil Haram. Every where you are, turn your face on him. And actually the people (Jews and Christians) who were

${ }^{1}$ Zainuddin Al Malibari, Fathu Al Mu'in Bi Syarhi Qurrati Al Aini Bi Muhimmati Al Diin (Beirut: Dar Ibnu Hazm, 2004), 40. 
given the Book (Torah and Gospel) do know that turning to the Masjidil Haram is true of their Lord; and Allah never neglects what they do" ${ }^{2}$

Currently there are various equipments to determine the direction of the Qibla, including using the istiwa stick ', rubu' mujayyab, compass, astrolabe, mizwala, istiwa'aini, theodolite and so on. ${ }^{3}$ There are two methods that are often used to determine the direction of the Qibla, namely utilizing the shadows of the Qibla and utilizing true north. What is meant by Qibla shadows are shadows that are formed from exposure to sunlight so that an object will form a shadow on the side that is not hit by the light, and there are several times when the shadows will lead to the Qibla. Meanwhile utillizing true north is to take advantage of geographic north or true north, true north is different from magnetic north or compass north, ${ }^{4}$ because this north direction has a declination deviation according to its location from true north. The method used to determine the direction of the Qibla through true north is to determine true north first, then calculate the qibla direction at that place.

Both methods have developed, from the calculation method to the instruments that support the determination of the Qibla direction. The determination of the direction of the Qibla can also developed digitally, namely by combining the previous method of determining the direction of the Qibla with technological developments such as making digital instrumentation to determine the direction of the Qibla such as theodolite, calculations that utilize computational systems, making applications for determining the direction of the Qibla on computers and smartphones. This is a manifestation of the efforts and development of astronomy in terms of determining the direction of the Qibla to keep up with the times or technological developments that

\footnotetext{
${ }^{2}$ Kemenag RI, Al-Quran Dan Terjemahnya (Jakarta: Kementerian Agama RI, 2018), 28.

${ }^{3}$ Siti Tatmainul Qulub, "Ilmu Falak Dari Sejarah Ke Teori Dan Aplikasi,” Depok: Rajawali Pers, 2017, $18-22$.

${ }^{4}$ Suci Novira Aditiani, Dyah Fitriana Masithoh, and Nonoh Siti Aminah, "Penentuan Arah Kiblat Dengan Metode Segitiga Bola," in Prosiding Seminar Nasional Fisika Dan Pendidikan Fisika (SNFPF) Ke, vol. 6, 2015, 38.
} 
aimed to make it easier to do something, in this case, determine the direction of the Qibla. ${ }^{5}$

One of the developments in the method of determining the direction of the Qibla is the determination of rashdul qibla, which is a method of determining the direction of the Qibla that uses the shadows of the Qibla at a certain time. This method is quite effective because if the calculation, time and place are suitable, the image of an object will be facing the Qibla. To illustrate, the case during the istiwa' a'dlom or rasdul qibla global event which occurred on 27/28 May at 11:57 LMT (Local Mean Time) and 15/16 July at 12:06 LMT. ${ }^{6}$ Similarly, the method that is almost the same as utilizing the shadows of the Qibla which can be used every day or is called the local rasdul qibla, on the basis of a certain location and place you will find shadows that lead to the Qibla almost every day.

This method is effective enough to be used as a comparison for determining the direction of the Qibla which can be used daily. Moreover, the calculation method can be utilized and modified digitally, by using a computational system. The Rasdul Qibla method can be converted into a diagram that can be used practically to determine the time when local rasdul qibla occurs every day, and the calculation can be converted into a device called the Qibla Diagram.

\section{B. Research Method}

This research is a qualitative research based on exploration. Primary and secondary data were collected by experiment and documentation, processed through three stages, namely codification, presentation and conclusions. Then the data will be analyzed by using descriptive analysis with the method of inductive thinking.

\footnotetext{
${ }^{5}$ Zainul Arifin, “Akurasi Google Earth Dalam Pengukuran Arah Kiblat," Ulumuddin: Jurnal Ilmu-Ilmu Keislaman 7, no. 2 (2017): 140.

${ }^{6}$ Local Mean Time (LMT) means mecca time, when it converted to Indonesian time, LMT +4 hours 20 minutes. Therefore, it becomes 16.18 WIB on 27/28 May and 16.27 on 15/16 July. It caused by the Sun's declination which almost similar to place latitude of Ka'ba. Slamet Hambali, "Ilmu Falak 1: Penentuan Awal Waktu Shalat \& Arah Kiblat Seluruh Dunia,” Semarang: Program Pascasarjana IAIN Walisongo, 2011, 192.
} 


\section{Discussion and Results}

\section{C.1. Qibla Direction and the Development of Its Determination Method}

Qibla direction consists of two words, namely direction and qibla. Direction in the Big Indonesian Dictionary (KBBI) means the direction, goal or purpose, ${ }^{7}$ while in Arabic, the word direction is called jihhah or syatrah. ${ }^{8}$ Then, the word qibla is an Arabic word namely qiblah, which is rooted from قبل,يقبل,قبلة means facing. ${ }^{9}$ Meanwhile, in the Big Indonesian Dictionary, the word Qibla means the direction to the Ka'ba in Mecca while someone is praying, it also means the direction or points of the compass. ${ }^{10}$ In addition, Slamet Hambali in his book "Ilmu Falak 1" quoted Muhammad Al Katib Al Asyarbini's opinion saying that Qibla means the direction as the following words: ${ }^{11}$

\section{والقبلة في اللغة : الجههة والمراد هنا الكعبة}

"Qibla according to language means Qibla, and what is meant by Qibla here is Ka'ba."

Qibla direction according to astronomical terminology is the closest direction to the Ka'bah from a place and passes through the large circle of the Earth ball and it must be done when Muslims pray. ${ }^{12}$ It means that the direction of the Qibla is a direction that must have clear provisions, because it relates to the coordinates of a place, namely the Ka'ba and the location where someone will pray. Consequently, clear provisions are needed to know the desired direction, in this case the direction what is meant is the direction indicated by a circle of $360^{\circ}$ (degrees) or commonly known as azimuth.

${ }^{7}$ https://kbbi.web.id/arah accessed on 10-01-2021 at 23:20 WIB.

${ }^{8}$ Munawwir Ahmad Warson, “Al-Munawwir Kamus Arab-Indonesia," Surabaya: Pustaka Progresif, 1997, 1088.

${ }^{9}$ Warson, 1088.

${ }^{10}$ https://kbbi.web.id/kiblat accessed on 10-01-2021 at 23:20 WIB.

${ }^{11}$ Hambali, "Ilmu Falak 1: Penentuan Awal Waktu Shalat \& Arah Kiblat Seluruh Dunia," 167.

${ }^{12}$ Ahmad Izzuddin, "Metode Penentuan Arah Kiblat Dan Akurasinya," in Conference Proceedings: Annual International Conference on Islamic Studies (AICIS) XII, 5 - 8 November 2012, Surabaya - Indonesia. (Surabaya: Universitas Islam Negeri Sunan Ampel, 2012), 771. http://digilib.uinsby.ac.id/8702/. 
At the time of the Prophet Muhammad, Qibla direction could be determined directly because at that time Islam was developing in Mecca and its surroundings, therefore facing the Qibla was done with Ainul Ka'bah. ${ }^{13}$ This is because the Qibla direction has transferred from the Ka'ba to the Baitul Maqdis when the Prophet Muhammad (peace be upon him) migrated to Medina for 16 months. Then the Q.S. al-Baqarah verse 144 instructs Rasulullah SAW and Muslims to face the Ka'ba as the qibla when praying, while in Medina and the direction of the Qibla has moved to the Ka'bah, the direction of the Qibla follows the mihrab of the Prophet's Mosque. This is considered the same as Ainul Ka'bah because facing the Qibla in the Prophet's Mosque is a revelation when Rasulullah SAW was ordered to face the Ka'ba as the qibla when praying.

During sahabat and tabi'in era, Islam experienced rapid development in the land of Arabia, so that mosques began to be built in these places such as the Amru bin Ash Mosque in Egypt which was built by Amru bin Ash (21 H / 641642 AD), The Qairawan Mosque built by Uqbah bin Nafi '(50-55 H / 670-675 AD), and the Banu Umayyah Mosque in Syria or Damascus built by Khalid bin Walid (88-97 H / 706-715 AD). ${ }^{14}$ These mosques are also known as Maharib alQadimah or the first mihrab (mosque) in the era of sahabat to tabi'in where according to the 4 imams of the fiqh madzhab following the direction of the Qibla of the mosque which has the nickname maharib al-qadimah, especially when someone does not know how to determine the qibla. ${ }^{15}$ Furthermore, the method used to determine the direction of the Qibla in the era of the 4th Imam Madzhab Fiqh is the ijtihadi method. The ijtihadi method is an attempt to determine the direction of the Qibla by using knowledge and someone who has mastered the knowledge of the direction of the Qibla and assistance that can show directions

\footnotetext{
${ }^{13}$ Ainul Ka'bah is facing ka'ba building directly with our five sense when we are close to Ka'ba and we can seet it directly. For example when we are in Masjidil Haram or stay in Mecca where there is no border to see Ka'ba, Abdurrahman Al Jaziri, Figh 'Ala Al-Madzahib Al-Arba'Ah, 1st ed. (Istanbul: Ih;as Gazetacilik A.S, 2004), 201.

${ }^{14}$ David A King, "Dan Gibson, Early Islamic Qiblas: A Survey of Mosques Built between 1AH/622 CE and 263 AH/876 CE (with Maps, Charts and Photographs), 296 Pp., Vancouver BC: Independent Scholars Press, 2017," Suhayl. International Journal for the History of the Exact and Natural Sciences in Islamic Civilisation, 2018, 356, 357, dan 360.

${ }^{15}$ Jaziri, Fiqh 'Ala Al-Madzahib Al-Arba'Ah, 203-205.
} 
such as wind, celestial bodies like the Sun, Moon, Planets and Stars. This method is used when a person is not around the Ka'bah, or is not in the Nabawi mosque, or is not in the maharib al-qadimah area, if that person has the knowledge to determine Qibla direction is allowed to use this method. ${ }^{16}$ Meanwhile, when we can not see qibla directly, so, facing the Qibla is called jihhatul Ka'bah.

After the emergence of astronomers in the $9^{\text {th }}$ century such as al-Battani who developed Ptolemy's theory of the spherical shape of the earth. Then the mathematical calculation method to determine the direction of the Qibla was discovered by Habash al-Hasib in 850 AD where the formula was used until currently as the qibla direction formula. Then the formula was redeveloped by AnNayrizi in 900 AD in Baghdad resulting in a method and tool called Zij. Furthermore the development of the formula for determining the direction of the Qibla was developed by Ibn Yunus in 980 AD in Cairo, and the spherical trigonometric formula was developed by Abu al -Wafa in 975 AD. After that, it was redeveloped by Ibn Al-Haytam in 1025 in Cairo and Al-Biruni in the same year in Central Asia. ${ }^{17}$

This calculation method then developed into an instrumentation or tool that helps to observe the direction of the Qibla such as the stick of istiwa ', mizwala, astrolabe and rubu' mujayyab. Since various methods of calculation, observation and instrumentation have been developed, determining the direction of the Qibla became easier. Moreover, the digital era helps any calculations can be converted to digital by computation process. This is because of the development of computer technology. Recently, determining Qibla direction can be developed largely, both redeveloped and instrumentation the current method or discover new method or instrumentation such as compass. Nevertheless, compass needs correction when it is used to determine qibla direction. Another example is theodolite, which actually is not used to determine qibla direction, but it can be used to determine qibla direction since it basic function is to determine the direction. The digital developments are expanded to application on computer or

\footnotetext{
${ }^{16}$ Jaziri, 203-6.

${ }^{17}$ Roshdi Rashed, Encyclopedia of the History of Arabic Science (Routledge, 2019), 142-47.
} 
smartphone, such as Mawaqit Program 2001 which is developed by Dr. Ing Khafid, Hisab Falak, developed by Ir. Aminudin E.Ka, S in 2004, and Winhisab developed by Ministry of Religious Affairs of Indonesia. ${ }^{18}$

\section{The Concept of Rashdul Qibla}

Currently there are various ways to determine the direction of the Qibla, a concept that is often used to determine the direction of the Qibla is to use a spherical triangle which is assisted by Earth coordinates, namely latitude and longitude, this concept is found in various astronomical literature which already has the concept of a spherical triangle with the assumption that Earth is a giant ball that has the same size in every corner or in other words, the shape of the Earth in the calculation of a spherical triangle or spherical trigonometry is a perfectly spherical shape. ${ }^{19}$ Consequently, it is possible to find the direction of the Qibla with the concept of a triangle placed on the surface of the Earth with the main coordinates of latitude and longitude of the Ka'ba. Then the vertex is located at the coordinates of the north-pole and the third point is located in the coordinates of the place to be calculated. The concept of a spherical triangle or spherical trigonometry is slightly different with ordinary trigonometric formulas because the surface in ordinary trigonometry is a flat plane, while in spherical trigonometric calculations, the surface is curved to form a sphere. The concept of determining the Qibla direction using the Sun's reference actually developed with a variety of methods, one of the basic aspects of using the Sun as an object to determine the direction of the Qibla is the Qibla shadow which is also an easy object to use to determine direction, which in this case is to determine the qibla direction.

In general, this concept occurs because the daily pseudo circulation of the Sun that occurs every year will be seen moving from east to west, assuming the value of the east direction in the azimuth is $90^{\circ}$ with the Sun's declination

18 Achmad Jaelani et al., "Hisab Rukyat Menghadap Kiblat (Fiqh, Aplikasi Praktis, Fatwa, Dan Software)” (Pustaka Rizki Putra, 2012), 168.

${ }^{19}$ Anisah Budiwati, "Tongkat Istiwa ', Global Positioning System (GPS) Dan Google Earth Untuk Menentukan Titik Koordinat Bumi Dan Aplikasinya Dalam Penentuan Arah Kiblat,” Al-Ahkam 26, no. 1 (2016): 67 . 
that occurs at the end of the summer solstice is $23.5^{\circ 20}$ and The maximum declination of the Sun when the winter solstice is $-23.5^{\circ}{ }^{21}$. The declination of the Sun will roughly pass through the azimuth between 66.5 and 113.5 when it rises and when the sun sets it is in the west with an azimuth value of 270 . If we assume the maximum movement of declination the same as when it rises, which is 23.5 to the north and 23.5 to the south, then the azimuth of the sun when it sinks is between 246.5 to 293.5 with this condition the apparent movement of the sun is not straight, but turns from north east when it rises it leads south when going to the zenith then heads north west again when it will sink, thus between trips The pseudo daily of the Sun will be in the azimuth of the Qibla, this is when viewed from Indonesia in general. This concept is ta ken as the basis for making the Sun as a reference for determining the direction of the Qibla and this concept is adopted in the method of determining the direction of the Qibla called Rashdul Qibla.

Rashdul Kiblat is rooted from word al-rașdu (الرصد) and al-qiblah (القبلة). The word al-ras $d u$, its plural is Arșâdun, meaning snooping or lurking, ${ }^{22}$ then if we translate it in Falak context, it means observation. Generally, qibla from language perspective means direction or facing. Meanwhile, terminologically qibla means direction toward Ka'ba in Mecca. Therefore, if we combine word al-Ras du and al-Qiblah means the way toward Qibla (Ka'ba). ${ }^{23}$ For Falak scholars (Falakiyyin), it means a concept which explain how to calculate and observe qibla direction by using a certain time, while the shadow of a thing directed to Ka'ba or known as "al-Syamsu Fî Madâri al- Qiblah". ${ }^{24}$ In the other word rasdul

${ }^{20}$ The Summer Solstice is the time when the declination of the Sun is at its peak when it is on the north side, which is $23.5 \mathrm{U}$, this event occurs approximately on June 21 each year, this event can also be called the peak of summer.

${ }^{21}$ The Winter Solstice is the opposite of the summer solstice, which is the lowest point of the Sun's declination, which is 23.5, S, occurring around December 22, also known as the winter peak.

22 Warson, "Al-Munawwir Kamus Arab-Indonesia," 501.

23 The writing of Rashdul Qibla should be written in accordance with the transliteration writing guidelines, namely rașdu al-qiblah, but this term is commonly used in journals and science books, so the author uses this term in writing the word rashdul qibla.

${ }^{24}$ Ahmad Izzuddin, Ilmu Falak Praktis: Metode Hisab-Rukyat: Praktis Dan Solusi Permasalahannya (Pustaka Rizki Putra, 2012), 45. 
qiblat has the same purpose as Istiwa' A'dlom or the main Istiwa'. It occurred when Sun's declination coincide with the latitude of Ka'ba, so its shadow will direct to Ka'ba.

The concept of Rashdul Qibla is one of the concepts of finding a practical Qibla direction, because it uses the shadows of the Qibla directly without predicting the direction in advance like other methods of determining the direction of the Qibla. ${ }^{25}$ The shadow of an object at a certain time in a place will show the direction of the Qibla, this is because the azimuth of the Sun and the azimuth of the Qibla have the same value or reverse direction, besides that Rashdul Qibla can also be caused because the position of the Sun is right above the Ka'ba, so at that time happens it will show the direction of the qibla.

\section{Kinds of Rashdul Qibla}

Slamet Hambali on his book "Ilmu Falak: Penentuan Awal Waktu Salat dan Arah Kiblat Seluruh Dunia (Falak Science: Determining of the Beginning of Praying time and Qibla Direction around the World)" divided Rashdul Qibla into two categories namely Global Rashdul Qibla and Local Rashdul Qibla. Globla

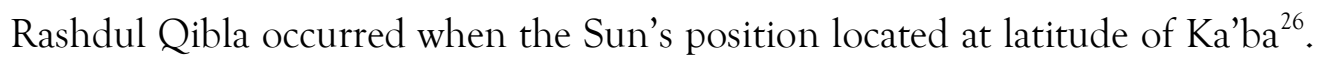
It happened twice in a year; 27/28 May and 15/16 July. ${ }^{27}$ While the Local Rashdul Qibla occurs when the Sun's azimuth is the same as the Qibla azimuth or the Sun's azimuth has a direction of 180 degrees from the Qibla azimuth. In the case of local Rashdul Qibla, it takes a certain hour so that every day there is a certain time that can be used to determine the direction of the Qibla through this method. Local Rashdul Qibla is a method of measuring the direction of the Qibla by utilizing the position of the Sun when it cuts the Qibla circle somewhere, so that all objects that are upright at that time have their shadow

\footnotetext{
${ }^{25}$ Izzuddin, 45.

${ }^{26}$ Lintang Kakbah yang dimaksud adalah 21 25’21,04” LU, Slamet Hambali, "Ilmu Falak Arah Kiblat Setiap Saat,” Yogyakarta: Pustaka Ilmu Yogyakarta, 2013, 14.

${ }^{27}$ Sayful Mujab, "Qiblat Tiap Saat Sebagai Jembatan Penentu Arah Qiblat," YUDISIA: Jurnal Pemikiran Hukum Dan Hukum Islam 6, no. 1 (2016): 168.
} 
showing the direction of the Qibla in that place, provided that the position of the Sun is on the east side (morning) for Indonesian time. This is because the direction of Indonesia's qibla is in the west-north direction, if the qibla shadow is in the east (in the afternoon) then the rashdul qibla is the opposite of the direction of the image.

\section{A Method to Determine Rashdul Qibla}

\section{The Global of Rashdul Qibla}

The global of Rashdul Qibla can be formulated as follow;

a. Determine latitude and longitude of Kakbah, Latitude $\left(\varphi^{\mathrm{k}}\right)=$ 21 25'21,04” LU (North Latitude), Longitude Kakbah $\left(\lambda^{\mathrm{k}}\right)=$ $39^{\circ} 49^{\prime} 34,33^{\prime \prime}$ BT (East Longitude); ${ }^{28}$

b. Determining latitude and longitude of a place (both latitude and longitude can be found in GPS, Google Earth, or GPS on a Smartphone);

c. Determine the longitude of the area of the Ka'bah, namely $45^{\circ}$ degrees and the longitude of the calculated location, the longitude value of the area is a multiple of $15^{\circ}$ from the value of the nearest place longitude, for example if the longitude of the place is $110^{\circ} 19^{\prime} 24$ "East Longitude (BT), then the longitude of the area is $105^{\circ}$, from the longitude of this area it can also be known the time zone, namely the longitude of the area $/ 15$, for example the longitude of the area $105 / 15=7$, then the time zone is +7 GMT, while the time zone of Mecca is $45 / 15=+3$ GMT. Longitude and time zone are affected by the location of the longitude, if it is east longitude then the value is positive, if longitude is west the value is negative;

d. Determining the occurrence of the zawal at the Ka'bah, this is because if the declination of the Sun is equal or close to the latitude of the Ka'ba,

${ }^{28}$ Earth coordinates consist of two parts, namely Latitude and Longitude, Latitude or lalitude consists of 2 parts, namely North Latitude (LU) with positive notation $(+)$ and South Latitude with negative notation (-), Longitude or longitude consists of 2 parts, namely East Longitude (BT) with positive notation $(+)$ and West Longitude (BB) with negative notation (-). 
then that is when the global Rashdul Kibla occurs, the formula for finding the zawal time $=12-\mathrm{e}\left(\mathrm{B}^{\mathrm{d}}-\mathrm{B}^{\mathrm{t}}\right) / 15$, then the zawal time of the Ka'bah $=12-\mathrm{e}+\left(45^{\circ}-39^{\circ} 49^{\prime} 34,33^{\prime \prime}\right) / 15$, (e is the equation of time $)$;

e. The difference between the time zone of the Ka'ba and the place of observation, if the longitude of the place is more east than the longitude of the Ka'ba, then the formula is the observation time zone - the Ka'ba time zone. Meanwhile, if the longitude of the area is further west than the longitude of the Ka'ba area, then the formula is the Ka'ba time zone (Bdk) - the observation time zone ( Bdo), for example if the longitude of the area is $105^{\circ}(+7$ GMT) then the time zone difference is +7 GMT - +3 GMT $=+4$ hours, then the time zone difference is +4 hours; $^{29}$

f. Determining the Rashdul Qibla time at the place of observation, the formula is the Makkah zawal time + the difference in time zones, the Makkah zawal time formula can be shortened to the global Rashdul Kibla time, as follow $=12-\mathrm{e}+\left(45^{\circ}-39^{\circ} 49^{\prime} 34,33\right.$ ") $/ 15+$ difference of time zones.

For example:

The Global Rashdul Qibla in Semarang occurred in 27 May 2021

The Sun's Declination occurred in 27 May 2021 which the declination is close to Ka'bah latitude when the Sun located on the Zenith of Ka'ba latitude; 21 21'29" (hour 9 UT or 12 LMT) and equation of time or e yaitu: $2 \mathrm{~m} 49 \mathrm{s.}^{30}$ Then the coordinate of Semarang, for example in Masjid Agung Jawa Tengah is $06^{\circ} 59^{\prime} 05^{\prime \prime}$ LS, $110^{\circ} 26^{\prime} 47^{\prime}$ BT, so we can find the rashdul qibla as follow;

$=12-0^{\circ} 2^{\prime} 49^{\prime \prime}+\left(45^{\circ}-39^{\circ} 49^{\prime} 34,33^{\prime \prime}\right) / 15$

$=12^{\circ} 17^{\prime} 52,71^{\prime \prime}$ LMT

${ }^{29}$ Global rashdul qibla occurs when the declination of the Sun coincides with the latitude of the Kaaba when the zawal is at the Ka'bah, while the rașdul qibla can only be counted when the sun is above the horizon, so the area of the global rașdul qibla occurs at 45 West Longitude ( -3 GMT) to the longitude of the region $135^{\circ}$ East Longitude (+9 GMT) taking into account the time of publication is 6 o'clock and sunset is 18 o'clock.

30 Kementerian Agama RI, Ephemeris Hisab Rukyat Kementerian Agama RI 2021 (Jakarta: Kementerian Agama RI, 2021).RI, 175.

Al-Hilal: Journal of Islamic Astronomy, Vol. 3, No. 1, 2021

p-ISSN : 2775-1236 ; e-ISSN : 2775-2119 
The difference between west Indonesia time zone (WIB) and Mecca time zone is +4 hours, therefore:

$=12^{\circ} 17^{\prime} 52,71^{\prime \prime}+4$ hours

$=16^{\circ} 17^{\prime} 52,71^{\prime \prime}$, rounded to $16: 18 \mathrm{WIB}$

\section{The Local of Rashdul Qibla}

The local Rashdul Qibla is a method of determining the direction of the Qibla using the apparent path of the Sun that passes through the azimuth Qibla line. The Sun's path from the east is exactly $90^{\circ}$ when it rises to the west which is $270^{\circ}$ when Sunset. Then, there is a declination of the Sun with a value between $-23.5^{\circ}$ in the direction south to north as much as 23.5 . The solar azimuth is possible to pass through the azimuth line between 66.5 to 113.5 when it rises and the sun azimuth when it sinks is between 246.5 to 293.5, but when after rising until it will set, the azimuth value of this sun will change according to its direction.

The following is the pattern of the local rashdul qibla:

a. Determining latitude and longitude of Ka'bah;

b. Determing latitude and longitude of the location as well as the region;

c. Determining the qibla direction in the observation spot $(B)^{31}$

d. Finding the declination and equation of time on the desired date, the data can be taken from the Ephemeris Hisab Rukyat published by the Indonesian Ministry of Religion, Win Hisab, and so on. Both the declination and equation of time can be calculated using solar data calculations that the author will present on further discussion. The declination and equation of time taken are random data, because they don't know when the local Rashdul Qibla occurs, but random data collection can be represented by taking data at 12 o'clock local time.

e. Calculating the angle assistant $(\mathrm{U})^{32}$

\footnotetext{
${ }^{31}$ Formula for Qibla Direction Cotan $\mathrm{B}=\tan \varphi^{\mathrm{k}} \cdot \cos \varphi^{\mathrm{x}} / \sin \mathrm{C}-\sin \varphi^{\mathrm{x}} / \tan \mathrm{C}$, note $=\mathrm{B}$ is qibla direction, $\varphi^{\mathrm{k}}$ is latitude of Ka'ba, $\varphi^{\mathrm{x}}$ is latitude of place, $\mathrm{C}$ is the gap between Ka'ba and place longitude., Hambali, "Ilmu Falak 1: Penentuan Awal Waktu Shalat \& Arah Kiblat Seluruh Dunia,” 182.
} 
$\operatorname{cotan} \mathrm{U}=\tan \mathrm{B} \cdot \sin \varphi^{\mathrm{x}}$

f. Calculating $(t-U)$

$\cos (\mathrm{t}-\mathrm{U})=\tan \delta^{\mathrm{m}} \cdot \cos \mathrm{U} / \tan \varphi^{\mathrm{x}}$

g. Calculating the angle time $(\mathrm{t})^{33}$

$\mathrm{t}=\mathrm{t}-\mathrm{U}+\mathrm{U}$

Then the angle time divided by 15

$\mathrm{t} / 15$

h. Calculating the local rashdul qibla (WH)

If the qibla direction inclined to the west, so $\mathrm{WH}=\mathrm{pkl} 12+\mathrm{t}$, but if the qibla direction inclined to the east, so $\mathrm{WH}=\mathrm{pkl} 12-\mathrm{t}$.

i. Calculating regional time (WD)

WD $=W H-e+\left(\lambda D^{x}-\lambda^{x}\right) / 15$

This result considered as approximation/ taqriri, and after we can find the approximation of rashdul qibla hour, then the declination data and equation of time can be determined during rashdul qibla hour.

j. Finding the declination data and equation of time when rashdul qibla is occurred. The method is by using interpolation, that taking a data from two data. By knowing the declination $\delta \mathrm{m}(\mathrm{A})$ as the first declination data and the declination $\delta \mathrm{m}(\mathrm{B})$ as the second declination with data intervals $\mathrm{A}$ and $\mathrm{B}$ is one hour, then determining data $\mathrm{C}$, which is the excess of minutes on the declination data, for example at $8^{\circ} 30^{\prime} 9$ ", then $\mathrm{C}$ is $0^{\circ} 30^{\prime} 9 "$, the formula $\delta \mathrm{m}$ interpolation $=\mathrm{A}+\mathrm{C}$. $(\mathrm{B}-\mathrm{A})$.

This interpolation formula is also applicable to find the equation of time data.

k. Calculating $\mathrm{t}-\mathrm{U}, \mathrm{t}, \mathrm{WH}$ and $\mathrm{WD}$ by using declination data and equation of time from interpolation version.

$$
\begin{aligned}
& \cos (\mathrm{t}-\mathrm{U})=\tan \delta^{\mathrm{m}} \cdot \cos \mathrm{U} / \tan \varphi^{\mathrm{x}} \\
& \mathrm{t}=\mathrm{t}-\mathrm{U}+\mathrm{U}
\end{aligned}
$$

32 The rashdul qibla's formula is referred from Hambali, 192-193., moreover it is also referred from qibla direction tan, see Izzuddin, Ilmu Falak Praktis: Metode Hisab-Rukyat: Praktis Dan Solusi Permasalahannya, 49.

${ }^{33}$ If you want to calculate the Rashdul Qibla time twice in one day, the time angle formula will be two, namely $(t-U)+U$ as the first time, and $U-(t-U)$ as the second time. 
the result of angle time $(\mathrm{t}) / 15$

$\mathrm{WH}=12+\mathrm{t}$

$\mathrm{WD}=\mathrm{WH}-\mathrm{e}+\left(\lambda \mathrm{D}^{\mathrm{x}}-\lambda^{\mathrm{x}}\right) / 15$

The example:

The local rashdul qibla at Masjid Agung Jawa Tengah on 17 August 2021 ,

The coordinat location $\varphi^{\mathrm{x}}=06^{\circ} 59^{\prime} 05^{\prime \prime} \mathrm{LS}, \lambda^{\mathrm{x}}=110^{\circ} 26^{\prime} 47^{\prime \prime} \mathrm{BT}^{34}$ Regional Longitude $\left(\lambda D^{x}\right)=105^{\circ}$

The Sun's declination in the noon at the location (at 5 o'clock UT) on 17 august 2021 is $13^{\circ} 20^{\prime} 49^{\prime \prime}$,

Equation of time or (e) at 5 o'clock UT on 17 August 2021 is -4 m 06 s,

The qibla direction (B) is $65^{\circ} 30^{\prime} 20,90^{\prime \prime} \mathrm{UB}$

The qibla azimuth is $294^{\circ} 29^{\prime} 39,10^{\prime \prime}$ UTSB

$\operatorname{Cotan} U=\tan B \cdot \sin \varphi^{\mathrm{x}}$

Cotan U $=\tan 65^{\circ} 30^{\prime} 20,90^{\prime \prime} \cdot \sin -06^{\circ} 59^{\prime} 05^{\prime \prime}$

$\mathrm{U} \quad=-75^{\circ} 03^{\prime} 20,28^{\prime \prime}$

$\cos (\mathrm{t}-\mathrm{U})=\tan \delta^{\mathrm{m}} \cdot \cos \mathrm{U} / \tan \varphi^{\mathrm{x}}$

$\cos (\mathrm{t}-\mathrm{U})=\tan 13^{\circ} 20^{\prime} 49^{\prime \prime} \cdot \cos -75^{\circ} 03^{\prime} 20,28^{\prime \prime} / \tan -06^{\circ} 59^{\prime} 05^{\prime \prime}$

$\mathrm{t}-\mathrm{U}=119^{\circ} 57^{\prime} 37,49^{\prime \prime}$

$\mathrm{t} 1=\mathrm{t}-\mathrm{U}+\mathrm{U}$

$=119^{\circ} 57^{\prime} 37,49^{\prime \prime}+-75^{\circ} 03^{\prime} 20,28^{\prime \prime}$

$=44^{\circ} 54^{\prime} 17,21^{\prime \prime}$

$\mathrm{t} / 15=44^{\circ} 54^{\prime} 17,21^{\prime \prime} / 15$

$=02^{\circ} 59^{\prime} 37,15^{\prime \prime 35}$

$\mathrm{WH} \quad=12+\mathrm{t} / 15$

$=12+02^{\circ} 59^{\prime} 37,15^{\prime \prime}$

$=14^{\circ} 59^{\prime} 37,15^{\prime \prime}$

WD

$=\mathrm{WH}-\mathrm{e}+\left(\lambda \mathrm{D}^{\mathrm{x}}-\lambda^{\mathrm{x}}\right) / 15$

${ }^{34}$ Hambali, "Ilmu Falak 1: Penentuan Awal Waktu Shalat \& Arah Kiblat Seluruh Dunia,” 184.

${ }^{35}$ If the result is negative or below 0 degrees, it means that the Rasdul Qibla time is below 12 o'clock, if it is positive or more than 0 degrees then the Rasdul Qibla is more than 12 o'clock. 


$$
\begin{aligned}
& =14^{\circ} 59^{\prime} 37,15^{\prime \prime}-\left(-0^{\circ} 04^{\prime} 06^{\prime \prime}\right)+\left(105^{\circ}-110^{\circ} 26^{\prime} 47^{\prime \prime}\right) / 15 \\
& =14^{\circ} 41^{\prime} 56,01^{\prime \prime} \text { or at } 14: 41: 56 \text { WIB } \\
& =\mathrm{U}-(\mathrm{t}-\mathrm{U}) \\
& =-75^{\circ} 03^{\prime} 20,28^{\prime \prime}-119^{\circ} 57^{\prime} 37,49^{\prime \prime} \\
& =-195^{\circ} 00^{\prime} 57,77^{\prime \prime} \\
\mathrm{t} / 15 \quad & =-195^{\circ} 00^{\prime} 57,77^{\prime \prime} / 15 \\
& =-13^{\circ} 00^{\prime} 03,85^{\prime \prime} \\
\mathrm{WH} & =12+\mathrm{t} / 15 \\
& =12+-13^{\circ} 00^{\prime} 03,85^{\prime \prime} \\
& =-01^{\circ} 00^{\prime} 03,85^{\prime \prime} \text { or at } 22: 59: 56 \mathrm{WIB}
\end{aligned}
$$

The $\mathrm{t} 2$ formula in this example cannot be applied because both rashdul Qibla occur at night. The result is $-01^{\circ} 00^{\prime} 03.85^{\prime \prime}$ meaning that the time is less than 0 or midnight, therefore the result needs to be added by 24 , so the sun is at the azimuth of the Qibla. However, it occurs at night, precisely at 22:59:56 WIB, therefore this rashdul Qibla is not considered, because the sun cannot be observed, but in some areas, this formula can prove the existence of 2 times the Rashdul Qibla in 1 day. This result is taqriby (close to the truth), because it uses the Sun data in the noon with rashdul qibla hour between at 2 p.m. (14 WIB) and 3 p.m. (15 WIB). Therefore, the Sun's data should be changed and interpolated to deal with the hour as follow:

The Sun's Declination at 14 WIB / 7 UT (A) = 13॰19'13"

The Sun's Declination at 15 WIB / 8 UT (B) = 13॰18'25”

The difference between WD and A(14 41'56,01” - 14) (C)

$=00^{\circ} 41^{\prime} 56,01^{\prime \prime}$

Interpolation $(\mathrm{A}+\mathrm{C} \cdot(\mathrm{B}-\mathrm{A}))$

$=13^{\circ} 19^{\prime} 13^{\prime \prime}+00^{\circ} 41^{\prime} 56,01^{\prime \prime} .\left(13^{\circ} 18^{\prime} 25^{\prime \prime}-13^{\circ} 19^{\prime} 13^{\prime \prime}\right)$

Interpolating the declination $=\underline{13^{\circ} 18^{\prime} 39,45^{\prime \prime}}$

Equation of time at $14 \mathrm{WIB} / 7 \mathrm{UT}(\mathrm{A})$ $=-00^{\circ} 04^{\prime} 05^{\prime \prime}$

Equation of time at $15 \mathrm{WIB} / 8 \mathrm{UT}$ (B) $=-00^{\circ} 04^{\prime} 04^{\prime \prime}$

The difference between WD and A (1441'56,01”-14) 


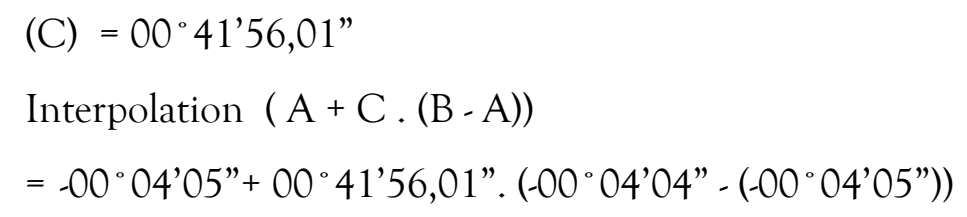

Repeat the calculation begin with $\cos (\mathrm{t}-\mathrm{U})$, but by using interpolation data of the sun

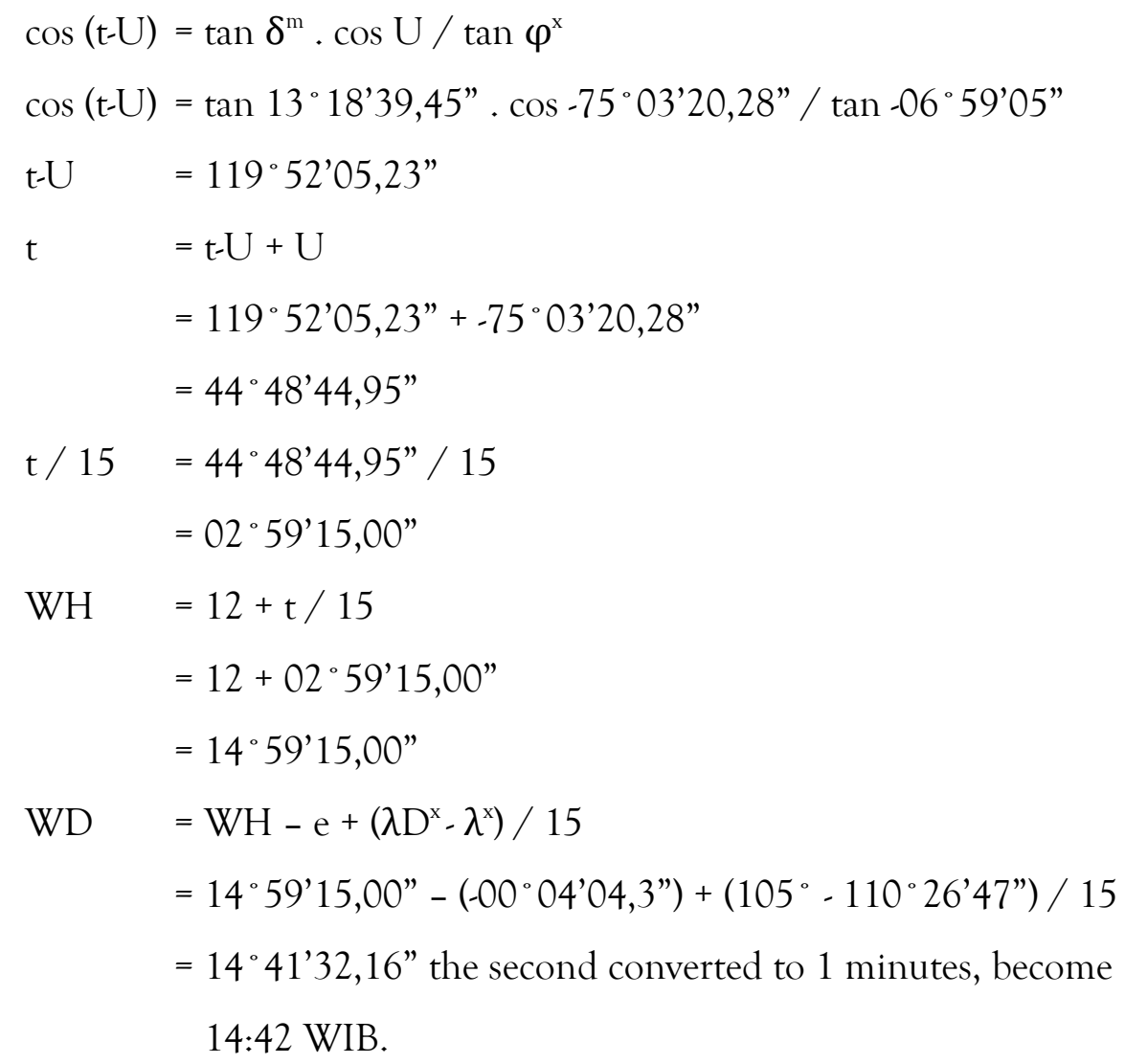

In conclusion, the local rashdul qibla at Masjid Agung Jawa Tengah at 17 August 2021 is at $14: 42$ WIB, meaning that during that time, the shadow of a thing will incline to around the qibla azimuth.

\section{C.2. Digitization of Rashdul Qibla}

Rashdul Qibla is basically a calculation used to determine the direction of the Qibla using the Qibla shadows. Therefore the Rashdul Qibla is a calculation system where the tools shown already exist, but without this calculation the tool cannot be used to determine the Rashdul Qibla. Because it requires continuity between calculations and the instruments used to determine the Rashdul Qibla. 
The calculation system at Rashdul Qibla has many steps when drawn back to the basic calculation of the movement of the sun and the appeared shadows. Therefore a manual system like this is not practically effective because it requires a long process, but without this calculation process it is not a more efficient calculation system will be created, consequently these calculations must be in place to create a digital calculation system.

Although the rashdul Qibla is a calculation system, it also has its own instrument, namely the image of the sun, more precisely there is an object that is perpendicular to show a shadow of an object that can cast a shadow, this object is usually called a gnomon. The result of this image of the gnomon, this calculation system can be interpreted as a Qibla direction indicator, therefore this tool is categorized as a basic analog instrument. This is because the calculation and reading system from the tool is separated and can only be linked if both are used simultaneously.

Based on the discovery of the Rashdul Qibla calculation system in the previous discussion and its supporting instruments such as the gnomon and the Qibla map. The authors combine the calculation system into a digital calculation system and utilize simple calculation software, namely Microsoft Excel to create calculation models that can be used automatically and practically as well as the output data can be converted into a tool that has a rashdul qibla diagram. It was inspired by the qibla map above and the gnomon to show the shadows of the qibla, so the tool is called the Qibla Diagram.

The application of the diagram to create data about rashdul qibla comes from a graph or bar chart of the declination of the Sun which has hills and valleys. It means that it has a minimum and maximum point that is far from zero, then the data can be converted into a circle, by utilizing automatic calculation results which assembled by the number processor. The change in the rashdul Qibla data is very dependent on the Sun's declination data, so the rashdul Qibla can be used as a circular data to make it easier to use, but if the data is created manually, it will generate a lot of errors and mistakes. Therefore it requires number processing tools such as Microsoft Excel to create these diagrams. 


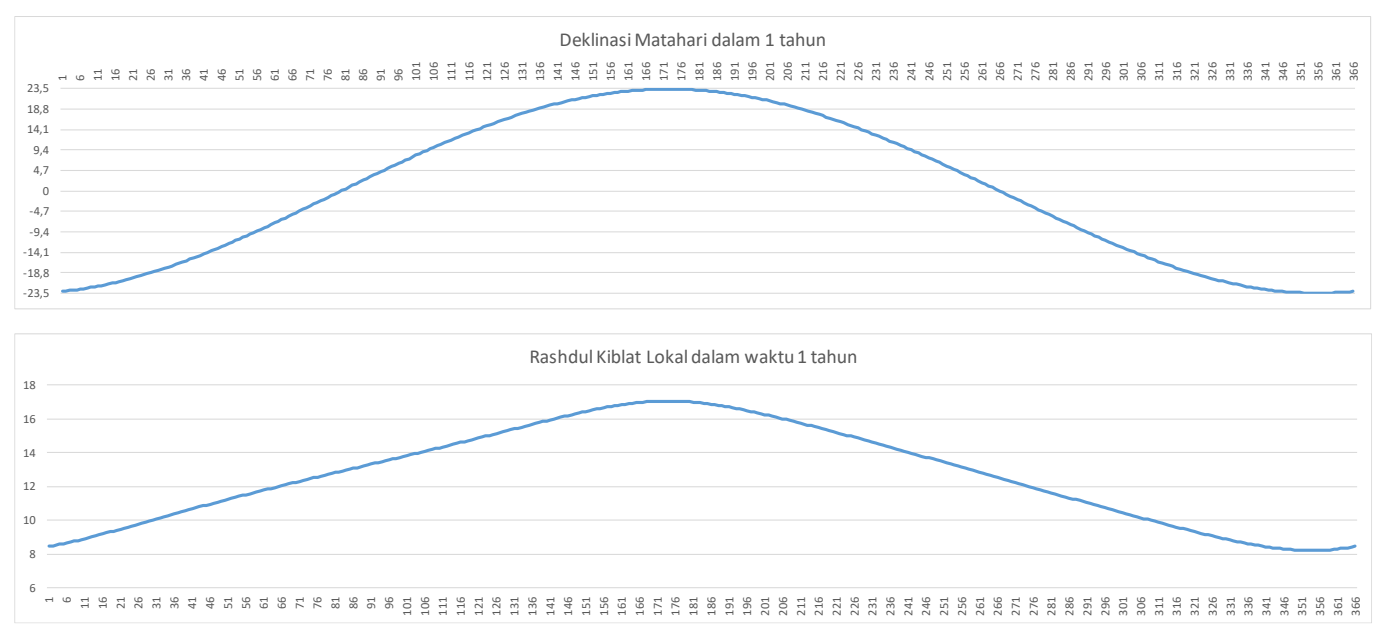

Image 1. A comparison between the sun's declination and local rashdul qibla in

Semarang

The diagram above can be a pie chart, but the function of the pie chart is not for mapping large amounts of data, so the alternative used is a radar diagram. A radar diagram is able to accommodate a lot of different data with the same time period. Moreover, it is because in its calculations, the local Rashdul Qibla is possible to occur twice in one day, so the use of radar charts is more effective than using pie charts.

The formation of the diagram was taken from the application of the formula and data of the Rashdul Qibla and the movement of the sun using the Jean Meeus algorithm in the book "Astronomical Algorithm". ${ }^{36}$ The book has been modified and adjusted to provide authomatic change for Qibla diagram. This authomatication is by changing the place coordinate, height, and the year of measurement.

36 Jean Meeus, “Astronomical Algorithms,” Richmond, 1991, 171-192.untuk mempermudah permudah perhitungan, dapat dilihat juga di Rinto Anugraha, "Mekanika Benda Langit," Yogyakarta: Jurusan Fisika Fakultas MIPA Universitas Gajah Mada, 2012, 63-80. 


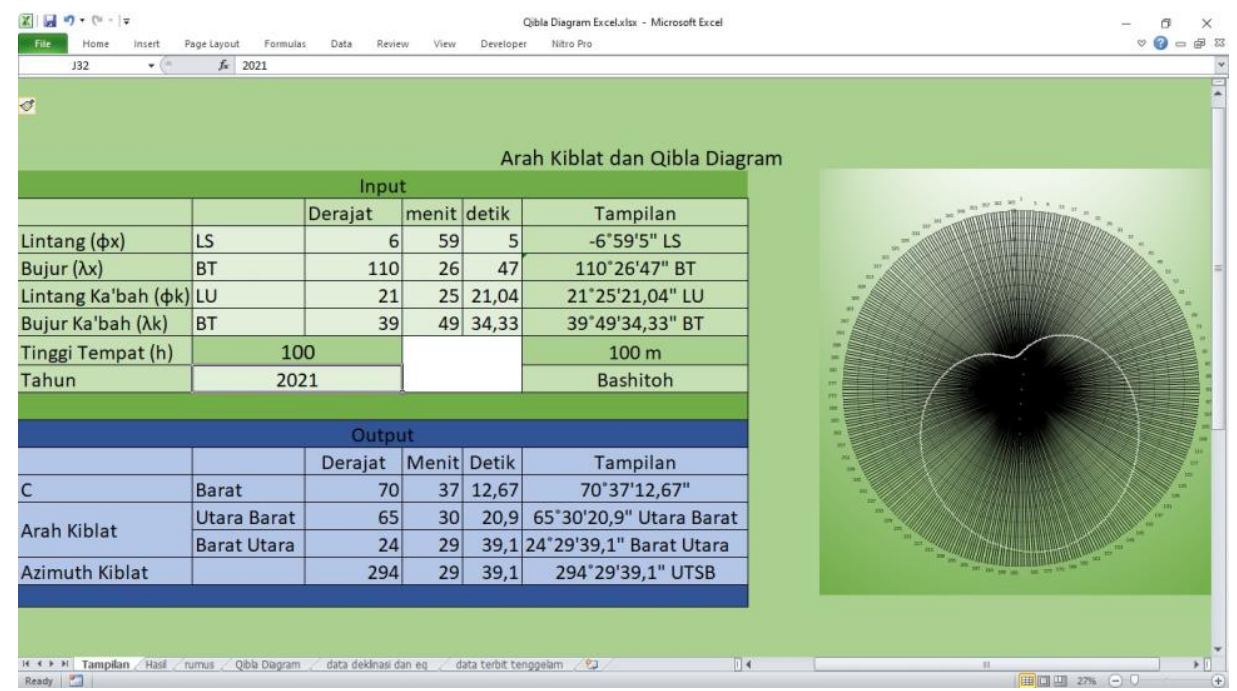

Image 2. The display of Qibla diagram program on Microsoft Excel

The display of Qibla diagram program on Microsoft Excel, contains of:

a. Display: contains data input, namely the latitude of the place, longitude of the place, latitude of the Ka'ba, longitude of the Ka'ba, the height of the place and the year. The latitude and longitude of a place used to find out the coordinates of the place. It can be known through a device such as a Garmin GPS or GPS found on a Smartphone; The latitude and longitude of the Ka'bah can be found through a lot of astronomy literature, while the author uses the Ka'ba coordinates used by Slamet Hambali in his book "Falak Science: Qibla Direction at Any Time (Ilmu Falak: Arah kiblat Setiap Saat)" where he quoted the Ka'ba coordinates from Google Earth in 2010. The coordinates of the Ka'ba he cited it is $21^{\circ} 25^{\prime} 21.04^{\prime \prime}$ North Latitude and $39^{\circ} 49^{\prime} 34.33^{\prime \prime}$ East Longitude; The height of the place serves to determine the time of sunrise and sunset. Then, year uses to determine the sun data adjusted for 1 year;

b. Result: contains the calculation results generated in the formula. Some results in this calculation are the local Rashdul Qibla Hour for one year, the table of rising, the culmination and setting of the sun for one year, the sun's declination, the equation of time and the solar azimuth which is calculated per 1 hour from 24 hours during one year;

c. Formula: consists of the local rashdul qibla formula as mentioned in the above discussion with input data for one year; 
d. Qibla Diagram: contains about changing the shape of the local rashdul qibla formula's result into a local rashdul qibla diagram;

e. Declination Data and Equation of Time: contains the formation of the formula for solar data per 1 hour from 24 hours for one year;

f. Sunrise, culmination and sunset data: contains formulas to determine the rising, culmination and setting of the sun. Its function is as a benchmark from the start and end of local rashdul qibla data. In this case, the author applies it due to the local rashdul qibla formula in some cases has twice the rashdul qibla and the data sometimes appears before sunrise or after sunset. Practically, this cannot be done because there are no objects that form a shadow, namely the sun. Consequently, the author made this formula to determine the right start and end for the Rashdul Qibla hour.

The use of the Qibla Diagram is local locally, so it requires re-processing of data if observations are made in remote areas. Therefore, besides the Qibla Diagram tool, a Qibla Diagram data processor is also needed, which the author compiles in Microsoft Excel. The way to use the data processor is to change latitude and longitude of the place to be measured. Then the height of the place (estimation data) and the year of measurement. Changes in the measurement year will affect changes in solar data.

\section{Qibla Diagram}

Qibla Diagram consists of two words, namely Qibla and Diagram. Qibla is the English pronunciation of Qiblah in the language of the direction or Kiblat in Indonesian, which means the place that Muslims go to when performing worship, namely the Ka'ba in Mecca. Then, Diagram is a graphical representation of value movements over a certain period of time and consists of the $\mathrm{x}$ (time) axis and the $\mathrm{y}$ (value) axis. Even though the name is only Qibla, what is meant is the local Rashdul Kibla, where the local Rashdul Kibla is a method of determining the direction of the Qibla using the azimuth of the sun's shadow when it is in contact with the qibla azimuth or its antipodal point in a certain place. While the diagram is a pie chart, so, Qibla Diagram means a 
tool in the form of a pie chart that can easily show the local Rashdul Qibla time by using the shadow of the Sun at a certain time.

The local Rashdul Qibla is a method of determining the direction of the Qibla using the sun's shadow when the Sun's azimuth or antipodal point coincided or equal to the Qibla azimuth in a certain area. Therefore the use of this method is an accurate method because it uses natural signs directly. However there are several things that need to be considered in carrying out calculations and practices in determining the direction of the Qibla using the local Rashdul Kibla method, namely the accuracy of the taken data and the process of field practice.

\section{Components of Qibla Diagram}

The author uses some components in making the Qibla Diagram. Those components are used for astronomical devices related to other shadows of the sun such as Mizwala and Istiwaain, because they have similar components, such as the presence of Gnomon or istiwa 'stick, rotary dial, layer dial, and feet dial. In addition, the author is also inspired by the presence of a directional needle that has two directions from a device called the Astrolabe, which functions as a marker for the hour and direction when the rashdul Qibla occurred. The overall components of the Qibla Diagram are the Gnomon, Rotary Dial Field, Hour and Direction indicator, Flat area and Feet Dial. 


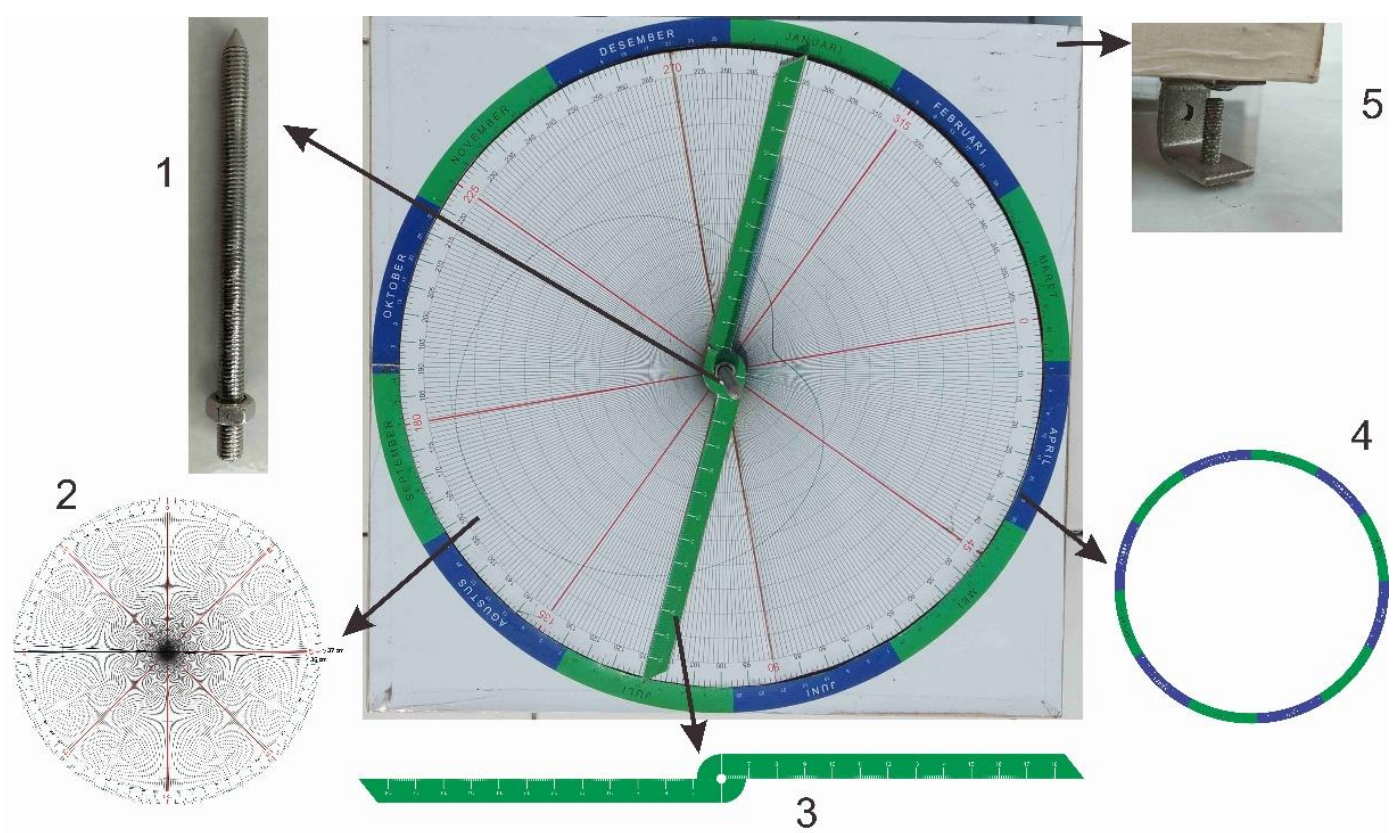

Image 3. Display of Qibla Diagram and Its Components

\section{The Used of Rashdul Qibla on Microsoft Excel Qibla Diagram}

The Qibla Diagram has two forms, namely the rashdul qibla calculation form and other complementary calculations in Microsoft Excel and the form of the instrument which combines the diagram and gnomon patterns to determine the time of the rashdul qibla. The use of the rashdul qibla on the Qibla Diagram can be done with the following steps: ${ }^{37}$

1) Input data which contained in the input column in the form of place latitude, place longitude, latitude of ka'ba, longitude of ka'ba, year and height of the place;

2) Give a sign LU if the latitude of the place being addressed is north latitude, and LS if the latitude is south latitude, for example the latitude of the Central Java Grand Mosque (Masjid Agung Jawa Tengah) is 06 59'05 "LS;

37 Muhammad Thoyfur, "Qibla Diagram in Excel" (Semarang, 2019), https://drive.google.com/drive/folders/1h5u4MzdU5iqjN2pZSm4z29c-8n9PCuha. 
3) Give a sign BT if the longitude of the place is east longitude and BB if the longitude of the place is west longitude, for example the longitude of the place of the Great Mosque of Central Java, is: $110^{\circ} 26^{\prime} 47^{\text {"BT; }}$

4) Latitude and longitude of ka'ba are allowed to be changed or it remain at the choice of the author, namely $21^{\circ} 25^{\prime} 21.04^{\prime \prime} \mathrm{LU}$ and 3949'34.33" BT;

5) Year used to change solar data on a one-year scale. The results can be seen in the results sheet next to Display. For example in 2020, the results will display 2020 data including February 29, which is the date of the leap (Kabisat) year;

6) If the altitude of the place is not known in detail, we can estimate the height of the place, for example; a coastal area the average height is not more than 10 meters.

The displayed result of the calculation will contains the following data;

a. Display

1. $\mathrm{C}$ is the difference between the longitude of the Ka'bah and the longitude of the area, this output functions to determine the inclination of the Qibla to be aimed;

2. Qibla direction, this result is the result of Qibla direction which is calculated from two sides in one quadrant, for example the Qibla direction of the Great Mosque of Central Java is 65 30'20,9" UB, meaning that the direction of the Qibla is viewed from north to west, and the results Another Qibla direction is $24^{\circ} 29^{\prime} 39,1^{\prime}$ BU, meaning that the direction of the Qibla is seen from the west to the north. Both results are still in one quadrant or $90^{\circ}$, the result of one of these Qibla directions will be used to calculate the rashdul Qibla;

3. Azimut Kibla, this result is the result of the Qibla direction which is calculated from north to east to the intended direction, for example the azimuth qibla of the Great Mosque of Central Java is 294 29'39.1" UTSB. This result is usually used as a reference when calculating directions the qibla is viewed using a true north reference; 
4. Qibla Diagram display, this result is a depiction of the Qibla Diagram tool by displaying the shape of the local rashdul qibla generated within one year in the form of a pie chart.

b. Results can be seen by pointing to the results of the calculation data which are located below the output.

1. The declination of the sun, this result is the result of calculating solar data per 1 hour for one year;

2. Local Rashdul Qibla Hour, this result is a clock showing in detail the local Rashdul Qibla time for one year;

3. Data of sunrise and sunset, this result is the result of the time of sunrise, the culmination and sunset of the sun which functions as the initial, middle and final limits of the local rashdul qibla;

4. Equation of Time, this result is the result in the form of the equation of time per 1 hour for one year;

5. Sun Azimuth, these results provide data in the form of solar azimuth per 1 hour for one year.

\section{Determining Rashdul Qibla on Qibla Diagram}

How to use the Qibla Diagram instrument to find out the local rashdul Qibla is quite easy and does not require deep analysis to find out the rashdul Qibla hour. Here are the steps for using the Qibla Diagram to determine the local rashdul Qibla hour:

1) Make sure the Qibla Diagram data is in accordance with the location, this is because the Qibla Diagram has local coverage. However the local effect of this tool is not really detailed because it has a time lag of 5 minutes in the direction and time. Therefore it can be used within the scope of one city, for example data used in the Qibla Diagram is the data of the Great 
Mosque of Central Java, so this tool can be used for the scope of the Semarang city; ${ }^{38}$

2) Put the Qibla Diagram on a flat plane, use the water pass to ensure the plane is flat and use the foot of the dial which is located under the tool;

3) Put the number $0^{\circ}$ which is located on the dial on the 1 st of January on a flat plane, this functions to match the data for the day and time of the local Rashdul Qibla;

4) Move the direction pointer on the rotary dial, but without changing the position of the rotary dial so that the pointer is on the desired date, for example the direction pointer is aimed at June 21, then turn the direction towards June 21;

5) Observe the meeting point between the diagram points on the rotary dial and the o'clock on the direction pointer. The outline shows the time per 1 hour and the small line shows the time per 5 minutes, for example on June 21 , the meeting position of the point position on the rotary dial and the direction is 5:05 pm because the long line shows 17 o'clock and the small line shows 1 line, it means 5 minutes more;

6) Wait until 17:05 and observe the shadow produced by the gnomon. Then point the direction at the shadow produced by the gnomon when the time shows 17:05. That shadow is the Qibla shadow;

7) If the observation time is before the sun's culmination, then the direction shown by the shadow of the gnomon is the direction of the Qibla. Meanwhile, if the observation is made after the sun's culmination, then the antipod of the shadow shows the direction of the Qibla;

8) Pull the result of the shadow using a rope and make a line to make the result of the Qibla direction.

The results of this tool is comparative, meaning that to determine maximum results, observation practice can be carried out to show the direction of the Qibla within a few days to show maximum results. This is because the

${ }^{38}$ Muhammad Thoyfur, "Formulasi Rasdul Qiblat Lokal Dalam Qibla Diagram” (UIN Walisongo Semarang, 2019), 105-107. 
Qibla Diagram has a time span of 5 minutes on the direction pointer, so the tool can be used in a wide area scale.

\section{C.3. Analytical Comparison Instrument between Qibla Diagram Manual and Digital}

\section{Analysis}

The Qibla Diagram instrument both analogically or manually and digitally has the same formula and calculation method. However the results of these two instruments are differences. This is due to differences in the types, advantages and benefits of each of these instruments, for example the calculation of the rashdul Qibla at Microsoft Excel can achieve accuracy per second, even far below according to the formula that the author entered into the calculation. Nevertheless, the calculations have drawbacks, namely that they cannot observe results directly because the results are in the form of numbers, not a form of the image of an object. Similarly, the manual Qibla diagram instrument has limitations in the details of the time shown, so there is the possibility of reading the data incorrectly. This is because the size of the tool is not large, so it cannot cover the details of the time up to 1 minute, if the details are accomplished, it requires a tool with diameter a circle of $1.4 \mathrm{~m}$ with a record of 1 minute per $1 \mathrm{~mm}$ and the time required is 12 hours per radius. This is not beneficial because the tool is not efficient and cannot be moved anywhere. Thus summarizing time is better but has consequences of shortcomings in the details of the time. Here is a comparison of the results of the Qibla Diagram instrument manually and digitally:

\begin{tabular}{ccccc}
\hline No. & Date & Manual & Digital & Compairsson Gap \\
\hline 1 & 21 March & $12: 50$ & $12: 49$ & $00: 01$ \\
\hline 2 & 27 May & $16: 20$ & $16: 18$ & $00: 02$ \\
\hline 3 & 28 May & $16: 20$ & $16: 21$ & $00: 01$ \\
\hline 4 & 21 June & $17: 05$ & $17: 04$ & $00: 01$ \\
\hline 5 & 15 July & $16: 30$ & $16: 27$ & $00: 03$ \\
\hline 6 & 16 July & $16: 25$ & $16: 24$ & $00: 01$ \\
\hline 7 & 21 September & $12: 35$ & $12: 36$ & $00: 01$ \\
\hline 8 & 22 December & $08: 15$ & $08: 14$ & $00: 01$ \\
\hline
\end{tabular}


Tabel 1. The Result of Instrument Comparison between Qibla Diagram Digital and Manual in Semarang ${ }^{39}$

The comparison results of the two instruments show that the difference between the time gap between the rashdul Qibla is $0-3$ minutes. This is because the minimum scale of the Qibla Diagram is 5 minutes, therefore the accuracy can reach 3 minutes. In this case, author argues that it is still can be tolerated based on the tolerance limit for the rashdul Qibla time which is approximately 5 minutes ${ }^{40}$, but with a record of the time shown is one hour before or after the culmination, because at that time, the movement of the sun feels fast. Therefore, it is not effective if it is used to determine the rashdul qibla, as shown on March 21 and September 21 located in Semarang.

\section{The Benefits and Drawbacks of Qibla Diagram Manual and Digital}

The results of the research on the Rashdul Qibla above were made into two parts, namely the manual part in the form of the Qibla Diagram tool and the Digital in the form of the Qibla Diagram calculation on Microsoft Excel. These two methods have advantages and disadvantages in determining and practicing in the field as follows:

\begin{tabular}{|c|c|c|c|c|}
\hline \multirow{2}{*}{ No } & \multirow{2}{*}{ Aspect } & Manual (Qibla Diagram) & \multicolumn{2}{|c|}{ Digital (Microsoft Excel) } \\
\hline & & Disadvantages & Advantages & Disadvantages \\
\hline 1. & Desain & $\begin{array}{ll}\text { The tool is simply } & \text { It needs large } \\
\text { designed and model to meet } \\
\text { practically used. }\end{array}$ & $\begin{array}{l}\text { It is more } \\
\text { dynamic and easy } \\
\text { to be changed. }\end{array}$ & $\begin{array}{l}\text { It needs more } \\
\text { development to } \\
\text { apply the actual } \\
\text { application } \\
\text { optimally. }\end{array}$ \\
\hline & Usage & $\begin{array}{l}\text { We can use it It can be used } \\
\text { directly on the only at one } \\
\text { location. }\end{array}$ & $\begin{array}{l}\text { It can be used at } \\
\text { any places by } \\
\text { changing input } \\
\text { of the place } \\
\text { latitude and } \\
\text { longitude. }\end{array}$ & $\begin{array}{l}\text { It can be used by } \\
\text { any applications. }\end{array}$ \\
\hline 3. & & se the We & is easier to be & It needs \\
\hline
\end{tabular}

39 The samples data were taken from the events of the global qibla, namely 27 and 28 May, 15 and 16 July, as well as the position of the sun representing the March 21 (vernal equinox) and September 21 (autumnal equinox) and Solstice or the peak of the sun on June 21 and December 22.

${ }^{40}$ Thomas Djamaluddin, "Menyempurnakan Arah Kiblat Dari Bayangan Matahari," 2010, https://tdjamaluddin.wordpress.com/2010/04/15/menyempurnakan-arah-kiblat-dari-bayangan-Matahari/. Accessed on 11-01-2021, at 10:30 WIB. 


\begin{tabular}{|c|c|c|c|c|}
\hline & $\begin{array}{l}\text { shadow of the } \\
\text { Sun directly. }\end{array}$ & $\begin{array}{l}\text { understand the } \\
\text { concept of } \\
\text { diagram on the } \\
\text { tool (different } \\
\text { location needs } \\
\text { different } \\
\text { interpretation). }\end{array}$ & $\begin{array}{l}\text { understood. The } \\
\text { provided time on } \\
\text { the rashdul qibla } \\
\text { contains table } \\
\text { and diagram. }\end{array}$ & $\begin{array}{l}\text { tool to apply the } \\
\text { result data. }\end{array}$ \\
\hline 4. Accuracy & $\begin{array}{l}\text { It can be used for } \\
\text { a larger area (the } \\
\text { time accuracy is } 3 \\
\text { minutes). }\end{array}$ & $\begin{array}{l}\text { The } 3 \text { minutes } \\
\text { time accuracy } \\
\text { can reduce the } \\
\text { accuracy of } \\
\text { Qibla azimuth. }\end{array}$ & $\begin{array}{l}\text { The time } \\
\text { accuracy is really } \\
\text { significant which } \\
\text { reach to second } \\
\text { level. }\end{array}$ & $\begin{array}{l}\text { The second level } \\
\text { of time accuracy } \\
\text { is not exactly } \\
\text { applicable on the } \\
\text { field. }\end{array}$ \\
\hline $\begin{array}{ll}\text { 5. Data } \\
\text { interpretation }\end{array}$ & $\begin{array}{l}\text { It is easy to used, } \\
\text { although without } \\
\text { the calculation of } \\
\text { qibla direction } \\
\text { and rashdul qibla. }\end{array}$ & $\begin{array}{l}\text { We have to be } \\
\text { thorough to } \\
\text { ensure the data } \\
\text { accuracy. }\end{array}$ & $\begin{array}{l}\text { It can be } \\
\text { combined } \\
\text { between the table } \\
\text { and diagram, so, } \\
\text { it will be easier to } \\
\text { interpret the } \\
\text { data. }\end{array}$ & $\begin{array}{l}\text { We need to } \\
\text { understand the } \\
\text { concept of the } \\
\text { used application } \\
\text { (Microsoft excel). }\end{array}$ \\
\hline
\end{tabular}

\section{Conclusion}

From above detailed explanation we can conclude some points as follow:

Firstly, the development in determining qibla direction will continuously developed. One of this development is by using computation technology and digital. The important thing of technological development in determining qibla direction is instrumentation which support in observation and data collection. Therefore, the instrumentation of calculation and manual tool can be developed to be digital instrumentation. In this case, the author combines analog instrumentation or manual with digital, the both can be interconnected as a Qibla Diagram. The Qibla Diagram method is used to be additional component to the tool related to qibla direction such as astrolabe, mizwala, istiwa' ain, and so on.

Secondly, the above explained results show that both instruments in Qibla Diagram related to each other and have advantages as well as disadvantages. The calculation system on Microsoft Excel can find the accurate result and Qibla Diagram tool can observe the calculation result. Hence, manual instrument is still urgent as comparison of digital instrument in determining qibla direction. However, if we could 
combine these two instrument, we would see the more efficient tool. Therefore, the device can determine qibla direction using rashdul qibla method in public society. The author wishes the development of the instrument like Qibla Diagram can be continuously researched, so it can lead to a new discovery both theoretically and practically which are beneficial to the society and science.

\section{E. Bibliography}

Aditiani, Suci Novira, Dyah Fitriana Masithoh, and Nonoh Siti Aminah. "Penentuan Arah Kiblat Dengan Metode Segitiga Bola." In Prosiding Seminar Nasional Fisika Dan Pendidikan Fisika (SNFPF) Ke, 6:35, 2015.

Anugraha, Rinto. "Mekanika Benda Langit." Yogyakarta: Jurusan Fisika Fakultas MIPA Universitas Gajah Mada, 2012.

Arifin, Zainul. "Akurasi Google Earth Dalam Pengukuran Arah Kiblat.” Ulumuddin: Jurnal Ilmu-Ilmu Keislaman 7, no. 2 (2017): 137-46.

Budiwati, Anisah. “Tongkat Istiwa ', Global Positioning System (GPS) Dan Google Earth Untuk Menentukan Titik Koordinat Bumi Dan Aplikasinya Dalam Penentuan Arah Kiblat." Al-Ahkam 26, no. 1 (2016): 65-92.

Djamaluddin, Thomas. "Menyempurnakan Arah Kiblat Dari Bayangan Matahari," 2010. https://tdjamaluddin.wordpress.com/2010/04/15/menyempurnakan-arah-kiblat-daribayangan-Matahari/.

Hambali, Slamet. "Ilmu Falak 1: Penentuan Awal Waktu Shalat \& Arah Kiblat Seluruh Dunia.” Semarang: Program Pascasarjana IAIN Walisongo, 2011.

—_. "Ilmu Falak Arah Kiblat Setiap Saat.” Yogyakarta: Pustaka Ilmu Yogyakarta, 2013.

Izzuddin, Ahmad. Ilmu Falak Praktis: Metode Hisab-Rukyat: Praktis Dan Solusi Permasalahannya. Pustaka Rizki Putra, 2012.

—. "Metode Penentuan Arah Kiblat Dan Akurasinya." In Conference Proceedings: Annual 
International Conference on Islamic Studies (AICIS) XII, 5 - 8 November 2012, Surabaya Indonesia. Surabaya: Universitas Islam Negeri Sunan Ampel, 2012. http://digilib.uinsby.ac.id/8702/.

Jaelani, Achmad, Anisah Budiwati, Encep Abdul Rojak, Faqih Baidhawi, Mahya Laila, Hasna Tuddar Putri, Muhammad Manan Ma'nawi, Robi'atul Aslamiyah, Siti Muslifah, and Siti Tatmainul Qulub. "Hisab Rukyat Menghadap Kiblat (Fiqh, Aplikasi Praktis, Fatwa, Dan Software).” Pustaka Rizki Putra, 2012.

Jaziri, Abdurrahman Al. Fiqh 'Ala Al-Madzahib Al-Arba'Ah. 1st ed. Istanbul: Ih;as Gazetacilik A.S, 2004.

King, David A. "Dan Gibson, Early Islamic Qiblas: A Survey of Mosques Built between 1AH/622 CE and 263 AH/876 CE (with Maps, Charts and Photographs), 296 Pp., Vancouver BC: Independent Scholars Press, 2017.” Suhayl. International Journal for the History of the Exact and Natural Sciences in Islamic Civilisation, 2018, 347-66.

Malibari, Zainuddin Al. Fathu Al Mu'in Bi Syarhi Qurrati Al Aini Bi Muhimmati Al Diin. Beirut: Dar Ibnu Hazm, 2004.

Meeus, Jean. “Astronomical Algorithms.” Richmond, 1991.

Mujab, Sayful. "Qiblat Tiap Saat Sebagai Jembatan Penentu Arah Qiblat.” YUDISIA: Jurnal Pemikiran Hukum Dan Hukum Islam 6, no. 1 (2016): 160-80.

Qulub, Siti Tatmainul. "Ilmu Falak Dari Sejarah Ke Teori Dan Aplikasi.” Depok: Rajawali Pers, 2017.

Rashed, Roshdi. Encyclopedia of the History of Arabic Science. Routledge, 2019.

RI, Kemenag. Al-Quran Dan Terjemahnya. Jakarta: Kementerian Agama RI, 2018.

RI, Kementerian Agama. Ephemeris Hisab Rukyat Kementerian Agama RI 2021. Jakarta: Kementerian Agama RI, 2021.

Thoyfur, Muhammad. "Formulasi Rasdul Qiblat Lokal Dalam Qibla Diagram." UIN 
Walisongo Semarang, 2019.

- "Qibla Diagram in Excel." 2019. https://drive.google.com/drive/folders/1h5u4MzdU5iqjN2pZSm4z29c-8n9PCuha.

Warson, Munawwir Ahmad. "Al-Munawwir Kamus Arab-Indonesia.” Surabaya: Pustaka Progresif, 1997. 